\title{
Germ cell transplantation in pigs - advances and applications
}

\author{
I. Dobrinski
}

Center for Animal Transgenesis and Cerm Cell Research, School of Veterinary Medicine, University of Pennsylvania, 382 West Street Rd., Kennett Square, PA 19348, USA

Transplantation of germ cells from fertile donor mice to the testes of infertile recipient mice results in donor-derived spermatogenesis and transmission of the donor haplotype to offspring of recipient animals. In the pig, germ cells can be transplanted to a recipient testis by ultrasoundguided cannulation of the rete testis with delivery of cells by gravity flow. It is important to note that germ cell transplantation was successful between unrelated, immuno-competent pigs, whereas transplantation in rodents requires syngeneic or immuno-compromised recipients. Efficiency of colonization of the recipient testis by donor-derived germ cells can be improved by pretreatment of the recipient animal to deplete endogenous germ cells. Genetic manipulation of isolated germ line stem cells and subsequent transplantation will result in production of transgenic sperm. Transgenesis through the male germ line has tremendous potential in species like pigs where embryonic stem cell technology is not available and current options to generate transgenic animals are inefficient. Introduction of a genetic change prior to fertilization will circumvent problems associated with manipulation of early embryos and developmental abnormalities associated with somatic cell nuclear transfer and reprogramming. Viral transduction of germ cells prior to transplantation has been used to generate transgenic rodents and has also shown early promising results in pigs. Current research is directed toward improving protocols for isolation and culture of porcine male germ cells to increase efficiency of transgene transmission and to allow for gene targeting prior to germ cell transplantation. It is expected that germ cell transplantation will then provide a viable alternate approach to generate germ line transgenic pigs.

\section{Germ cell transplantation - basic aspects}

Spermatogenesis is a continuous, highly organized process comprised of sequential steps of cell proliferation and differentiation resulting in production of virtually unlimited numbers of spermatozoa throughout the life of the male (Russell et al., 1990). The foundation of this system is the spermatogonial stem cell, which has the unique potential for both self-renewal and production of differentiated daughter cells, and will ultimately form spermatozoa (Huckins, 1971; Clermont, 1972; Meistrich and van Beek, 1993). Among stem cells in a male individual, 
the spermatogonial stem cell is unique in that it is the only cell in an adult body that divides and contributes genes to subsequent generations making it a perfect target for genetic manipulations.

In 1994, Dr. Ralph Brinster and colleagues at the University of Pennsylvania reported that transplantation of germ cells from fertile donor mice to the testes of infertile recipient mice resulted in donor-derived spermatogenesis and sperm production by the recipient animal (Brinster and Zimmermann, 1994). Use of donor males carrying the bacterial B-galactosidase gene allowed for identification of donor-derived spermatogenesis in the recipient mouse testis and established the fact that the donor haplotype was passed on to offspring by recipient animals (Brinster and Avarbock, 1994).

In 1995, Jiang and Short applied the technique to germ cell transplantation between rats (subsequently also reported by Ogawa et al., 1999a; and Zhang et al., 2003), and in 1996, Brinster's group showed that mouse spermatogonial stem cells, cryopreserved for prolonged periods of time before transplantation, still established spermatogenesis in the recipient testis (Avarbock et al., 1996).

In recent years, germ cell transplantation studies provided new insights into different aspects of spermatogenesis. Germ cell transplantation in rodents made it possible to study the stem cell niche in the testis, and to characterize putative spermatogonial stem cells (Parreira et al., 1998; Nagano et al., 1999; Ventela et al., 2002). Cross-species transplantation established that the cell cycle during spermatogenesis is controlled by the germ cell and not the Sertoli cell (Franca et al., 1998). Also, sperm arising from transplanted donor germ cells were capable of fertilization in vivo and in vitro (Brinster and Avarbock, 1994; Goossens et al., 2003; Honaramooz et al., 2003a). Recently, transplantation experiments even demonstrated the developmental potential of mouse primordial germ cells to initiate spermatogenesis when transplanted into a post-natal testis (Chuma et al., 2005).

\section{Xenotransplantation of germ cells}

In 1996, production of rat sperm in mouse testes was achieved following cross-species (xenogeneic) spermatogonial transplantation from rats to mice (Clouthier et al., 1996) and was subsequently successful from mice to rats (Ogawa et al., 1999a; Zhang et al., 2003). For its obvious practical potential, cross-species germ cell transplantation was explored further. Hamster spermatogenesis occurred successfully in the mouse host (Ogawa et al., 1999b); however, with increasing phylogenetic distance between donor and recipient species, complete spermatogenesis could no longer be achieved in the mouse testis. Transplantation of germ cells from nonrodent donors ranging from rabbits and dogs to pigs and bulls, and ultimately non-human primates and humans, resulted in colonization of the mouse testis, but spermatogenesis became arrested at the stage of spermatogonial expansion (Dobrinski et al., 1999, 2000; Nagano et al., 2001a, 2002a). It appears that the initial steps of germ cell recognition by the Sertoli cells, localization to the basement membrane, and initiation of spermatogonial proliferation are conserved between evolutionary divergent species. However, it was hypothesized that with increasing phylogenetic distance between donor and recipient species, the recipient testicular environment (comprised of Sertoli cells and paracrine factors) becomes unable to support spermatogenic differentiation and meiosis. This incompatibility of donor germ cells and recipient testicular environment was overcome by co-transplantation of germ cells and Sertoli cells (Shinohara et al., 2003) or by testis tissue transplantation (Honaramooz et al., 2002). Although xenogeneic spermatogonial transplantation did not have the envisioned immediate practical application, it nonetheless provides a bioassay for stem cell potential of germ cells isolated 
from other species (Dobrinski et al., 1999; 2000; Izadyar et al., 2002) as well as an intriguing tool to study cellular and non-cellular requirements of spermatogenesis in diverse species.

\section{Germ cell transplantation in pigs}

Technical aspects

The application of germ cell transplantation technology to non-rodent species was initially difficult. Due to differences in testicular anatomy and physiology, germ cells cannot be delivered by the same technique as in rodents. Instead, we developed a technique combining ultrasound-guided cannulation of the centrally located rete testis with delivery of germ cells by gravity flow. Fig. 1 outlines the different steps of the germ cell transplantation approach in the pig. With this technique, we succeeded in transplanting donor cells from pigs and goats to the testes of prepubertal recipient animals (Honaramooz et al., 2002; 2003a, b). Transplantation of donor cells from transgenic goats provided proof-of-principle that germ cell transplantation results in donor-derived sperm production and fertility in a large animal species (Honaramooz et al., 2003b). It is of interest to note that successful germ cell transplantation in rodents, and perhaps cattle, requires that recipient animals are either closely related to the donor or immunosuppressed (Kanatsu-Shinohara et al., 2003a; Zhang et al., 2003; Izadyar et al., 2003), whereas germ cell transplantation in pigs and goats was also successful between unrelated individuals (Honaramooz et al., 2002; 2003a, b). Experiments are now directed at improving the efficiency of germ cell transplantation in domestic animals by enrichment for stem cells and suppression of recipient spermatogenesis as discussed below.

\section{Donor}

collect donor testis cells

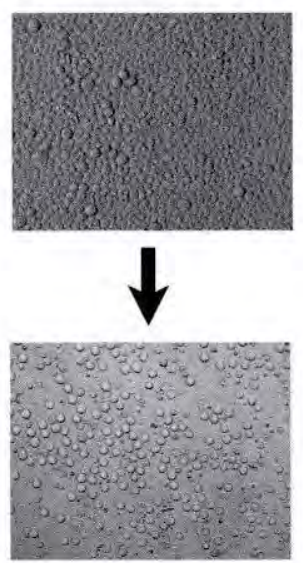

enrich germ cells, culture

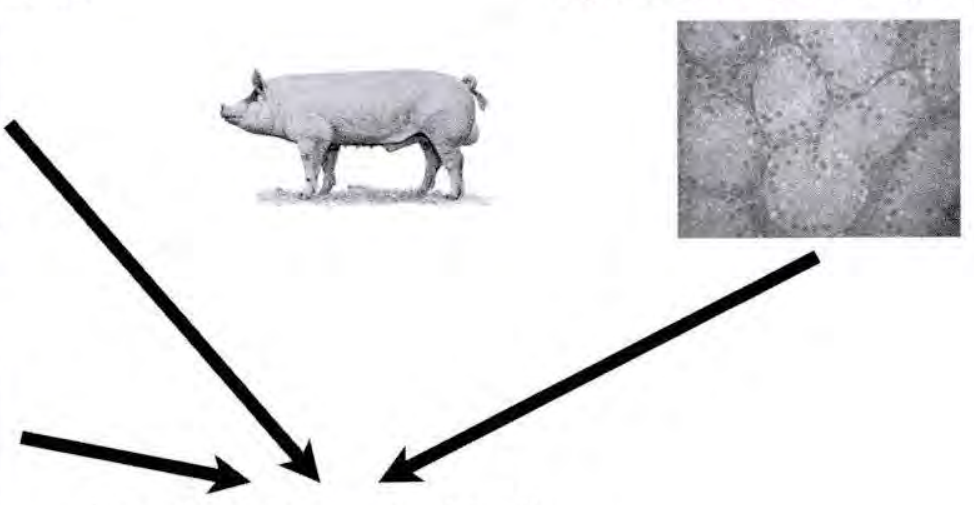

transplant to recipient testis

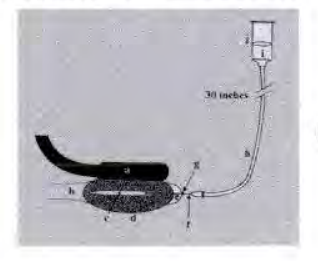

Recipient deplete endogenous germ cells

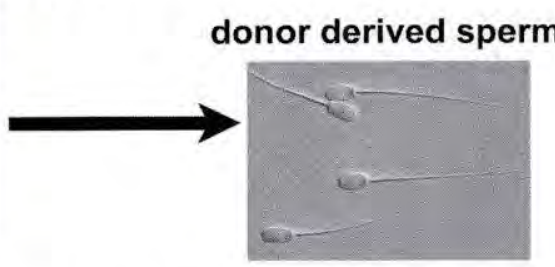

Fig. 1 Schematic representation of germ cell transplantation in the pig 


\section{Recipient animal preparation}

On the recipient side, using young mice and treating recipients with $\mathrm{GnRH}$-agonists improved donor cell colonization (Shinohara et al., 2001, Ogawa et al., 1998, 1999a; Dobrinski et al., 2001). Efficiency of colonization of seminiferous tubules by the transplanted germ cells can be optimized, if the recipient testes have little or no endogenous spermatogonia. Busulfan, a DNA alkylating agent that destroys proliferating cells, is frequently used in rodents to deplete recipient germ cells prior to germ cell transplantation. However, the sterilizing dose of busulfan is species- and strain-specific, and treatment can be lethal due to severe bone marrow depression (Ogawa et al., 1999a; Brinster et al., 2003). We, therefore, designed a study to develop a practical protocol for depletion of endogenous spermatogonia in potential recipient pigs. Treatment of pigs with busulfan between 5 and 17 weeks of age resulted in a significant reduction of testis weight and germ cell number, but also in systemic toxicity. Therefore, treatment in utero was explored as previously described in the mouse (Brinster et al., 2003). Administration of busulfan to pregnant sows at days 98 and 108 of gestation (a period of high proliferation of foetal gonocytes) resulted in depletion of gonocytes with no observed adverse effects on the piglets or on sow health or fertility (Honaramooz et al., 2004). The number of germ cells was significantly reduced at $2-8$ weeks of age compared to untreated controls. At 16 weeks of age, when recipient pigs would be used for transplantation, only $8 \%$ of seminiferous tubules showed initiation of spermatogenesis compared to $100 \%$ in controls. It was shown previously in rodents that a complete suppression of spermatogenesis might not be desirable in recipient animals as some residual endogenous spermatogenesis is an indication that the testicular environment has not been permanently damaged by the cytotoxic treatment (Brinster et al., 2003). Therefore, late gestation in utero treatment of pigs with busulfan provided a suitable testis environment for subsequent germ cell transplantation.

\section{Germ cell culture}

It has been estimated that there are only about $2 \times 10^{4}$ stem cells in $10^{8}$ cells of a mouse testis (Meistrich and van Beek, 1993; Tegelenbosch and de Rooij, 1993). In order to study the biology of spermatogonial stem cells in vitro and to increase colonization efficiency after transplantation in vivo, it is desirable to obtain populations of cells enriched in spermatogonial stem cells from testis cell preparations. In the mouse, selection of germ cells for expression of $\alpha_{6}$-and $\beta_{1}$-integrin in the absence of c-kit receptor, as well as collection of cells from experimentally induced cryptorchid testes, resulted in a significant enrichment for spermatogonial stem cells (Shinohara et al., 1999, 2000a, b). More recently, expression of either Thy-1, CD9 or Egr3, surface proteins, also expressed on embryonic or bone marrow stem cells, was utilized as markers for enrichment of mouse germ line stem cell populations (Kubota et al., 2003, 2004; Kanatsu-Shinohara et al., 2004; Hamra et al., 2004). One previous report in pigs described the use of sedimentation at unit gravity (Staput) to obtain cell fractions highly enriched in type A spermatogonia (Dirami et al., 1999). However, the approaches based on flow sorting, magnetic cell sorting or Staput to obtain the larger numbers of germ cells needed for transplantation are not very practical in the pig. Therefore, we are currently exploring enrichment strategies based on differential adhesion to plastic and extracellular matrix as previously reported in rodents (Shinohara et al., 1999; Orwig et al., 2002a). Early experiments showed promising results with porcine germ cells. In addition, donor age affects the number of germ cells present in the testis and also the relative number of putative spermatogonial stem cells in the total cell population (Shinohara et al., 2001). Harvesting donor germ cells from animals just before puberty when spermatogonia and Sertoli cells are the only cell types present in the seminiferous tubules will assure that the relative number of germ cells collected from the donor testis will be maximized. 
Nagano et al. (1998) were the first to show that mouse germ line stem cells could be maintained in culture for a long period of time. Improving culture conditions for male germ line stem cells is still under intense study as evidenced by recent reports of improved culture systems for mouse germ cells (Kanatsu-Shinohara et al., 2003b, 2005; Jeong et al., 2003). Coculture with embryonic fibroblast or bone marrow stromal cells, but not Sertoli cell lines, and addition of several growth factors known to be beneficial for culture of other stem cell types or primordial germ cells, such as glial cell-line derived neurotrophic factor (GDNF), leukemia inhibitory factor (LIF), epidermal growth factor (EGF), and basic fibroblast growth factor (bFGF), successfully maintained mouse germline stem cells in culture for varying periods of time (Nagano et al., 1998; 2003; Kanatsu-Shinohara et al., 2003b). Recently, Dr. Brinster's group reported an efficient long-term culture system for mouse spermatogonial stem cells (Kubota et al., 2004) that is now being tested for its potential to maintain pig germ cells in vitro. Immortalized cell lines would provide tremendous potential for the study and manipulation male germ cells in vitro. To date, there are reports of three immortalized germ cell lines from rat and mouse (van Pelt et al., 2002; Feng et al., 2002; Hofmann et al. 2005), and similar immortalization strategies might hold promise for porcine germ cells.

\section{Applications of germ cell transplantation in pigs}

Germ cell transplantation is a powerful approach to study control of spermatogenesis with the ultimate goal to enhance or suppress male fertility. It also provides an opportunity to preserve genetic material of valuable males. Germ cell transplantation has an advantage over the only approach currently available, cryopreservation of sperm, in that it can be applied to prepubertal animals where sperm cannot be obtained or even to adults rendered azoospermic or teratozoospermic by disease. It has also been discussed as a toof to store genetic material from barrows used in performance testing in lieu of using littermates of the top quality animals for breeding. Another potential application would be delivery of genetic material to a closed production herd through resident recipient animals.

Perhaps the most intriguing application of the technique will be the transplantation of transfected germ cells as an alternate means to generate transgenic animals. Although to date the lack of pure starting populations of germ line stem cells and optimized culture systems have made this a difficult task, some success was reported in generating transgenic mice and rats by retroviral or lentiviral transduction of germ cells prior to transplantation (Nagano et al. 2001b, 2002b; Hamra et al., 2002; Orwig et al., 2002b). In one report, a transgene introduced using a retroviral vector was stably integrated and passed on to subsequent generations without gene silencing (Nagano et al., 2001b). Since putative stem cells are considered to be replicating very slowly or not at all when cultured, viral gene therapy vectors that integrate into non-replicating cells are an obvious choice for gene transfer. Recombinant adeno-associated virus (rAAV) is a replication-defective, non-pathogenic human parvovirus that stably and site-specifically integrates into dividing and non-dividing human cells. It infects cells of different species, and therefore, does not require pseudotyping, readily integrates into quiescent cells in a short period of time and does not carry the same level of biosafety concerns as lentiviral vectors. Transduction of porcine germ cells using rAAV prior to transplantation showed promising results (Honaramooz et al., 2003c), and is a topic of current investigation. However, AAV vectors accommodate only relatively small genetic insertions and have the potential for episomal integration and gene silencing. Therefore, use of other viral and non-viral transfection systems still needs to be further explored in porcine germ cells.

Practical application of transgenesis through germ cell transplantation is ultimately dependent on improvements in efficiency of stem cell selection, transfection and culture. Efficient 
culture systems that support maintenance and expansion of stem cells are of utmost importance as they would permit gene targeting approaches and cell selection prior to transplantation. Transgenesis through the male germline using transplantation of genetically modified germ cells has tremendous potential in species like pigs where embryonic stem cell technology is not available. Current options to generate genetically modified pigs include pronuclear microinjection of DNA (Hammer et al., 1985) and nuclear transfer technology using modified donor cells (Lai et al., 2002; Park et al., 2002; Hyun et al., 2003; Phelps et al., 2003; Kolber-Simonds et al., 2004), as well as sperm mediated DNA transfer (Lazzereschi et al., 2000; Lavitrano et al., $2002,2003)$. However, currently available technology is frequently fraught with low efficiency and developmental abnormalities in the few resulting offspring, making the approach of using germ cell transplantation a potentially very valuable alternative. Introduction of a genetic modification prior to fertilization will circumvent problems associated with manipulation of gametes and early embryos and developmental abnormalities associated with nuclear reprogramming. In addition, even if embryonic stem cell technology becomes available for pigs, the time required until transgenic sperm can be harvested will be significantly shorter using germ cell transplantation (Fig. 2).

A

transfect donor cells
(ES cells)

inject blastocysts

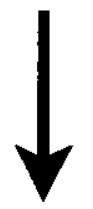

birth of chimeric male

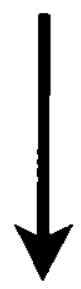

collect transgenic and wild-type sperm/breed
B

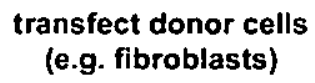

nuclear transfer

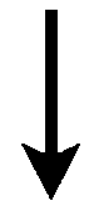

birth of transgenic male piglet

Time to puberty $(7 \mathrm{mo})$

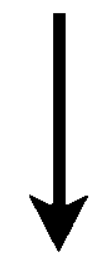

collect transgenic sperm/breed
C

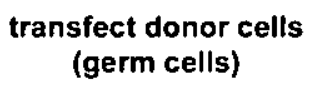

transplantation to testis of prepubertal recipient

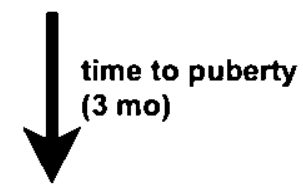

collect transgenic and wild-type sperm/breed

Fig. 2 Comparison of three different approaches to transgenesis. A: Transgene introduction through embryonic stem cells (Note: This has been adapted in principle from work in rodents as the technology is currently not available in pigs); $\mathrm{B}$ : Transgenesis through somatic cell nuclear transfer (cloning); $C$ : Transgenesis through germ cell transplantation (work in progress).

Introduction of a genetic modification before meiosis will allow for recombination to occur. A recipient animal, therefore, can produce sperm with different transgene integrations that may permit screening of offspring to select the most desirable genotype. Finally, genetic manipulation of male germ line stem cells may provide an approach to generate males that produce unisex sperm by introducing a sex-linked mutation that selectively prevents formation of hap- 
loid cells carrying either an $X$ or a $Y$ chromosome. Production of all male or all female offspring is of economic interest to different production systems. In addition, in the pig it might provide an avenue to avoid routine castration of male piglets, a procedure that is coming under increasing scrutiny due to animal welfare concerns.

\section{Conclusions}

Germ cell transplantation was initially developed in rodents. Application to a large domestic animal species was first reported in the pig and subsequently in goats and cattle. Important aspects of the approach, including isolation of donor cells, delivery to recipient testes and recipient animal preparation have been established in the pig while others such as long-term culture and expansion of germ cells in vitro and efficient introduction of stable genetic changes are still under investigation. Germ cell transplantation allows for preservation of male genetic material and introduction of genetic changes through the male germ line. It represents an approach to germ line manipulation through use of transgenic sperm for natural breeding that is potentially more efficient than currently existing strategies.

Work from the author's laboratory presented here was supported by 5R01 RR017359-04 (NCRR) $\mathrm{NIH).}$

\section{References}

Avarbock MR, Brinster Cl, Brinster RL (1996) Reconstitution of spermatogenesis from frozen spermatogonial stem cells Nature Medicine 2 693-696

Brinster RL, Avarbock MR (1994) Germline transmission of donor haplotype following spermatogonial transplantation Proceedings of the National Academy of Sciences USA 91 11303-11307

Brinster RL, Zimmermann JW (1994) Spermatogenesis following male germ-cell transplantation. Proceedings of the National Academy of Sciences USA 91 11298- 11302

Brinster CJ, Ryu B-Y, Avarbock MR, Karagenc L, Brinster RL, Orwig KE (2003) Restoration of fertility by germ cell transplantation requires effective recipient preparation Biology of Reproduction $69412-420$

Chuma $S$, Kanatsu-Shinohara $M$, Inoue K, Ogonuki $N$, Miki H, Toyokuni S, Hosokawa M, Nakatsuji N, Ogura A, Shinohara T (2005) Spermatogenesis from epiblast and primordial germ cells following transplantation into postnatal mouse testis Development 132 117-122

Clermont $Y$ (1972) Kinetics of spermatogenesis in mammals: seminiferous epithelium cycle and spermatogonial renewal Physiological Reviews 52 198-236

Clouthier DE, Avarbock MR, Maika SD, Hammer RE, Brinster RL (1996) Rat spermatogenesis in mouse testis. Nature $381 \quad 418-421$

Dirami G, Ravindranath N, Pursel V, Dym M (1999) Effects of stem cell factor and granulocyte macrophage-colony stimulating factor on survival of porcine type A spermatogonia cultured in KSOM Biology of Reproduction 61 225-230

Dobrinski I, Avarbock MR, Brinster RL (1999) Transplantation of germ cells from rabbits and dogs into mouse testes. Biology of Reproduction 61 1331-1339
Dobrinski I, Avarbock MR, Brinster RL (2000) Germ cell transplantation from large domestic animals into mouse testes Molecular Reproduction and Development $57 \quad 270-279$

Dobrinski I, Ogawa T, Avarbock MR, Brinster RL (2001) Effect of the GnRH-agonist leuprolide on colonization of recipient testes by donor spermatogonial stem cells after transplantation in mice Tissue and Cell 33 200-207

Feng L-X, Chen Y, Dettin L, Reijo Pera RA, Herr JC, Goldberg E, Dym M (2002) Generation and in vitro differentiation of a spermatogonial cell line Science $297 \quad 392-395$

Franca LR, Ogawa T, Avarbock MR, Brinster RL, Russell LD (1998) Germ cell genotype controls cell cycle during spermatogenesis in the rat Biology of Reproduction 59 1371-1377

Goossens E, Frederickx V, De Block G, Van Steirteghem A, Tournaye H (2003) Reproductive capacity of sperm obtained after germ cell transplantation in a mouse model Human Reproduction 18 1874-1880

Hammer RE, Pursel VG, Rexroad CE, Wall RJ, Bolt DJ, Ebert KM, Palmiter RD, Brinster RL (1985) Production of transgenic rabbits, sheep and pigs by microinjection Nature 315 680-683

Hamra FK, Gatlin J, Chapman KM, Grellhest DM, Garcia JV, Hammer RE, Garbers DL (2002) Production of transgenic rats by lentiviral transduction of male germ-line stem cells Proceedings of the National Academy of Sciences USA 99 14931-14936

Hamra FK, Schultz N, Chapman KM, Grellhesl DM, Cronkhite IT, Hammer RE, Garbers DL (2004) Defining the spermatogonial stem cell Developmental Biology 269 393-410

Hofmann M-C, Braydich-Stolle L, Dettin L, Johnson E, 
Dym M (2005) Immortalization of mouse germ line stem cells Stem Cells 23 200-210

Honaramooz A, Megee SO, Dobrinski I (2002) Germ cell transplantation in pigs Biology of Reproduction $6021-28$

Honaramooz A, Behboodi E, Blash, S, Megee SO, Dobrinski I (2003a) Germ cell transplantation in goats Molecular Reproduction and Development 64422 . 428

Honaramooz A, Behboodi E, Megee SO, Overton SA, Galantino-Homer HL, Echelard Y, Dobrinski I (2003b) Fertility and germline transmission of donor haplotype following germ cell transplantation in immunocompetent goats Biology of Reproduction 69 1260-1264

Honaramooz A, Megee S, Foley B, Dobrinski I (2003c) Use of adeno-associated virus for transfection of male germ cells for transplantation in pigs Theriogenology 59536

Honaramooz A, Hausler CL, Dobrinski I (2004) Chemical depletion of spermatogenesis to prepare recipients pigs for germ cell transplantation Biology of Reproduction Special Issue 261

Huckins C (1971) The spermatogonial stem cell population in adult rats. I. Their morphology, proliferation, and maturation Anatomical Record 160 533-558

Hyun S, Lee G, Kim D, Kim H, LEE S, Nam D, Jeong Y, Kim S, Yeom S, Kang S, Han J, Lee B, Hwang W (2003) Production of nuclear transfer-derived piglets using porcine foetal fibroblasts transfected with the enhanced green fluorescent protein Biology of Reproduction 69 1060-1068

Izadyar F, Matthijs-Rijsenbilt JJ, den Ouden K, Creemers LB, Woelders H, de Rooij DG (2002) Development of a cryopreservation protocol for type A spermatogonia Journal of Andrology 23 537-545

Izadyar F, den Ouden K, Stout TAE, Stout I, Coret J, Lankveld DPK, Spoormakers TJP, Colenbrander B, Oldenbroek JK, Van der Ploeg KD, Woelders H, Kal HB, de Rooij DG (2003) Autologous and homologous transplantation of bovine spermatogonial stem cells Reproduction $126 \quad 765-774$

Jeong D, McLean DJ, Griswold MD (2003) Long-term culture and transplantation of murine testicular germ cells Journal of Andrology 24 661-669

Jiang FX, Short RV (1995) Male germ cell transplantation in rats: apparent synchronization of spermatogenesis between host and donor seminiferous epithelia International Journal of Andrology 18 326-330

Kanatsu-Shinohara $M$, Ogonuki N, Inoue $K$, Miki $H$, Ogura A, Toyokuni S, Shinohara T (2003a) Longterm proliferation in culture and germline transmission of mouse male germline stem cells Biology of Reproduction 69 612-616

Kanatsu-Shinohara $\mathrm{M}$, Ogonuki N, Inoue K, Ogura A, Toyokuni S, Honjo T, Shinohara T (2003b) Allogeneic offspring produced by male germ line stem cell transplantation into infertile mouse testis Biology of Reproduction 68 167-173

Kanatsu-Shinohara M, Toyokuni S, Shinohara T (2004) CD9 is a surface marker on mouse and rat male germline stem cells Biology of Reproduction 7070 75

Kanatsu-Shinohara $M$, Miki $H$, Inoue K, Ogonuki N, Toyokuni S, Ogura A, Shinohara T (2005) Long-term culture of mouse male germline stem cells under serum- or feeder-free conditions Biology of Reproduction 72 985-991

Kolber-Simonds D, Lai L, Watt SR, Denaro M, Arn S, Augenstein ML, Betthauser J, Carter DB, Greenstein JL, Hao Y, Im G-S, Liu Z, Mell GD, Murphy CN, Park K-W, Rieke A, Ryan DIJ, Sachs DH, Forsberg EJ, Prather RS, Hawley RJ (2004) Production of alpha1,3-galactosyltransferase null pigs by means of nuclear transfer with fibroblasts bearing loss of heterozygosity mutations. Proceedings of the National Academy of Sciences USA $1017335-7340$

Kubota H, Avarbock MR, Brinster RL (2003) Spermatogonial stem cells share some, but not all, phenotypic and functional characteristics with other stem cells Proceedings of the National Academy of Sciences USA 1006487.6492

Kubota H, Avarbock MR, Brinster RL (2004) Culture conditions and single growth factors affect fate determination of mouse spermatogonial stem cells $\mathrm{Bi}$ ology of Reproduction $71722-731$

Lai L, Kolber-Simonds D, Park K-W, Cheong H-T, Greenstein JL, Im G-S, Samuel M, Bonk A, Rieke A, Day BN, Murphy CN, Carter DB, Hawley RJ, Prather RS (2002) Production of alpha-1,3-galactosyl-transferase knockout pigs by nuclear transfer cloning Science 295 1089-1092

Lavitrano $M$, Bacci $M L$, Forni $M$, Lazzereschi D, Di Stefano C, Fioretti D, Giancotti P, Marfe G, Pucci L, Renzi L, Wang H, Stoppacciaro A, Stassi C, Sargiacomo M, Sinibaldi P, Turchi V, Giovannoni R, Della Casa G, Seren E, Rossi G (2002) Efficient production by sperm-mediated gene transfer of human decay accelerating factor (hDAF) transgenic pigs for xenotransplantation Proceedings of the National Academy of Sciences USA $9914230-14235$

Lavitrano M, Forni M, Bacci ML, Di Stefano C, Varzi V, Wang H, Seren E (2003) Sperm mediated gene transfer in pig: Selection of donor boars and optimization of DNA uptake Molecular Reproduction and Development 64 284-291

Lazzereschi D, Forni M, Cappello F, Bacci ML, Di Stefano C, Marfe G, Giancotti P, Renzi L, Wang HJ, Rossi M, Della Casa G, Pretagostini R, Frati G, Bruzzone P, Stassi G, Stoppacciaro A, Turchi V, Cortesini R, Sinibaldi P, Frati L, Lavitrano M (2000) Efficiency of transgenesis using sperm-mediated gene transfer: Generation of hDAF transgenic pigs Transplantation Proceedings $32 \quad 892-894$

Meistrich ML, van Beek MEAB (1993) Spermatogonial stem cells. In Cell and Molecular Biology of Testis pp266-295 Eds C Desjardins and LL Ewing, Oxford University Press, New York, Oxford

Nagano M, Avarbock MR, Leonida EB, Brinster CJ, Brinster RL (1998) Culture of mouse spermatogonial stem cells Tissue and Cell 30 389-397

Nagano M, Avarbock MR, Brinster RL (1999) Pattern 
and kinetics of mouse donor spermatogonial stem cell colonization in recipient testes Biology of Reproduction 60 1429-1436

Nagano M, McCarrey JR, Brinster RL (2001a) Primate spermatogonial stem cells colonize mouse testes. Biology of Reproduction 64 1409-1416

Nagano M, Brinster Cl, Orwig KE, Ryu B-Y, Avarbock MR, Brinster RL (2001b) Transgenic mice produced by retroviral transduction of male germ-line stem cells Proceedings of the National Academy of Sciences USA 98 13090-13095

Nagano M, Patrizio P, Brinster RL (2002a) Long-term survival of human spermatogonial stem cells in mouse testes Fertility and Sterility $78 \quad 1225-1233$

Nagano M, Watson DJ, Ryu B-Y, Wolfe JH, Brinster RL (2002b) Lentiviral vector transduction of male germ line stem cells in mice FEBS Letters $524111-115$

Ogawa T, Dobrinski l, Avarbock MR, Brinster RL (1998) Leuprolide, a gonadotropin releasing hormone agonist, enhances colonization after spermatogonial transplantation into mouse testes Tissue and Cell $\mathbf{3 0}$ 583-588

Ogawa T, Dobrinski I, Brinster RL (1999a) Recipient preparation is critical for spermatogonial transplantation in the rat Tissue and Cell 31 461-472

Ogawa T, Dobrinski I, Avarbock MR, Brinster R (1999b) Xenogeneic spermatogenesis following transplantation of hamster germ cells to mouse testes Biology of Reproduction 60 515-521

Orwig KE, Shinohara T, Avarbock MR, Brinster RL (2002a) Functional analysis of stem cells in the adult rat testis Biology of Reproduction 66 944-949

Orwig KE, Avarbock MR, Brinster RL (2002b) Retrovirusmediated modification of male germline stem cells in rats Biology of Reproduction $67874-879$

Park K-W, Lai L, Cheong H-T, Cabot R, Sun Q-Y, Wu G, Rucker EB, Durtschi D, Bonk A, Samuel M, Rieke A, Day BN, Murphy CN, Carter DB, Prather RS (2002) Mosaic gene expression in nuclear transfer-derived embryos and the production of cloned transgenic pigs from ear-derived fibroblasts Biology of Reproduction 66 1001-1005

Parreira GC, Ogawa T, Avarbock MR, Franca LR, Brinster RL, Russell LD (1998) Development of germ cell transplants in mice Biology of Reproduction 59 13601370

Phelps CJ, Koike C, Vaught TD, Boone J, Wells KD, Chen S-H, Ball S, Specht SM, Polejaeva IA, Monahan JA, Jobst PM, Sharma SB, Lamborn AE, Garst AS,
Moore M, Demetris A\}, Rudert WA, Bottino R, Bertera S, Trucco M, Starzl TE, Dai Y, Ayares DL. (2003) Production of alpha1,3-galactosyltransferasedeficient pigs Science $299411-414$

Russell LD, Ettlin RA, SinhaHikim AP, Clegg ED(1990) Mammalian spermatogenesis. In Histological and Histopathological Evaluation of the Testis pp 1-40 Eds LD Russell, RA Ettlin, AP SinhaHikim and ED Clegg. Cache River Press, Clearwater

Shinohara T, Avarbock MR, Brinster RL (1999) beta1and alpha6-integrin are surface markers on mouse spermatogonial stem cells Proceedings of the National Academy of Sciences USA 96 5504-5509

Shinohara T, Avarbock MR, Brinster RL (2000a) Functional analysis of spermatogonial stem cells in Steel and cryptorchid infertile mouse models Developmental Biology 220 401-411

Shinohara T, Orwig KE, Avarbock MR, Brinster RL. (2000b) Spermatogonial stem cell enrichment by multiparameter selection of mouse testis cells Proceedings of the National Academy of Sciences USA 97 8346-8351

Shinohara T, Orwig KE, Avarbock MR, Brinster RL (2001) Remodeling of the postnatal mouse testis is accom, panied by dramatic changes in stem cell number and niche accessibility Proceedings of the National Academy of Sciences USA 98 6186-6191

Shinohara T, Orwig KE, Avarbock MR, Brinster RL (2003) Restoration of spermatogenesis in infertile mice by Sertoli cell transplantation Biology of Reproduction 68 1064-1071

Tegelenbosch RAJ, de Rooij DG (1993) A quantitative study of spermatogonial multiplication and stem cell renewal in the $\mathrm{C} 3 \mathrm{H} / 1 / 101 \mathrm{~F} 1$ hybrid mouse Mutation Research 290 193-200

van Pelt AMM, Roepers-Gajadien HL, Gademan IS, Creemers LB, de Rooij DG, van Dissel-Emiliani FMF (2002) Establishment of cell lines with rat spermatogonial stem cell characteristics Endocrinology 143 1845-1850

Ventela S, Ohta H, Parvinen M, Nishimune $Y$ (2002) Development of stages of the cycle in mouse seminiferous epithelium after transplantation of green fluorescent protein-labeled spermatogonial stem cells Biology of Reproduction 66 1422-1429

Zhang Z, Renfree MB, Short RV (2003) Successful intraand interspecific male germ cell transplantation in the rat Biology of Reproduction $68961-967$ 